\title{
Translational Review
}

\section{The Dopamine Paradox in Lung and Kidney Epithelia Sharing the Same Target but Operating Different Signaling Networks}

\author{
Alejandro M. Bertorello and Jacob I. Sznajder \\ Department of Medicine, Atherosclerosis Research Unit, Membrane Signaling Networks, Karolinska Institutet, Karolinska University Hospital, \\ Stockholm, Sweden; and Department of Medicine, Northwestern University, Feinberg School of Medicine, Chicago, Illinois
}

\begin{abstract}
Stimulation of dopamine receptors in the lung or kidney epithelia has distinct and opposite effects on the function of Na,K-ATPase, which results in increased $\mathrm{Na}^{+}$absorption across the alveolar epithelium and increased sodium excretion via the kidney epithelium. In the lung, dopamine increases $\mathrm{Na}, \mathrm{K}-\mathrm{ATPa}$ e by increasing cell basolateral surface expression of $\mathrm{Na}^{+}, \mathrm{K}^{+}$-ATPase molecules, whereas in the kidney epithelia it decreases $\mathrm{Na}^{+}, \mathrm{K}^{+}$-ATPase activity by removing active units from the plasma membrane by endocytosis. The opposite effects of dopamine over the same target (the $\mathrm{Na}^{+}, \mathrm{K}^{+}$ATPase) involve the activation of a distinct signaling network that it is target specific, and has a different spatial resolution. Understanding the specific signaling pathways involved in these actions of dopamine and their hierarchical organization may facilitate the drug discovery process that could lead to the design of new therapeutic approaches to clear lung edema in patients with acute lung injury and to decrease fluid overload during congestive heart failure and hypertension.
\end{abstract}

Keywords: $\mathrm{Na}^{+}, \mathrm{K}^{+}$-ATPase; endocytosis; $\mathrm{Na}^{+}$-transport

The kidney tubule cells and the lung alveolar epithelial cells share a common task that for simplicity can be summarized as an epithelial barrier that determines the amount of fluid and solutes that moves across two distinct compartments. As a result of this function, the renal tubule epithelium is critical for maintaining the extracellular volume and composition, whereas the lung alveolar epithelial Type I and Type II pneumocytes maintain the alveolar space free of fluid, which permits a normal $\mathrm{O}_{2}$ and $\mathrm{CO}_{2}$ gas exchange.

Movement of fluid and electrolytes across the epithelium of both lung and kidney is mediated by cell-specific transporters located in distinct areas of the cell membrane (Figure 1A). Although not completely understood, it is believed that such distribution of membrane transporters is organized and/or maintained largely by the presence of tight junctions. The polarized distribution of proteins regulating sodium transport is essential for vectorial transport in kidney and lung epithelia (1). The $\mathrm{Na}^{+}, \mathrm{K}^{+}$ATPase is located at the basolateral domain of both epithelial

(Received in final form August 2, 2005)

This work has been supported partially by funds from the Swedish Research Council (32X-10860 and 32P-14879), National Institutes of Health, USA (HL 65161 and HL 71643), the Swedish Heart \& Lung foundation, and the Karolinska Institutet.

Correspondence and requests for reprints should be addressed to Alejandro M. Bertorello, King Gustaf V Research Institute, Karolinska University Hospital, S-171 76 Stockholm, Sweden. E-mail: alejandro.bertorello@medks.ki.se, or to Jacob I. Sznajder, Department of Medicine, Northwestern University, Feinberg School of Medicine, Chicago, IL 60611. E-mail: j-sznajder@northwestern.edu

Am J Respir Cell Mol Biol Vol 33. pp 432-437, 2005

DOI: $10.1165 / \mathrm{rcmb} .2005-0297 T R$

Internet address: www.atsjournals.org cells and provides the driving force for active sodium transport across the cell, while the presence of different sodium transporters at the apical domain ensures its entry into the cells. During transit across the cell, the intracellular concentration remains tightly regulated to maintain cell volume homeostasis and other vital cell functions. These specific transporters are targeted by a wide variety of agents such as peptide hormones, catecholamines, and growth factors leading to short- and/or long-term adjustments in both lung and kidney epithelial cells responses to physiologic demands.

\section{SALT AND WATER TRANSPORT: PATHOPHYSIOLOGIC IMPACT WITHIN THE TARGET ORGANS}

During cardiogenic pulmonary edema alveolar flooding occurs only after protective compensatory mechanisms are overwhelmed. Although many patients with pulmonary edema from "heart failure" have elevated intravascular volume, a significant number are not fluid overloaded before the development of alveolar flooding. These patients have elevations in pulmonary vascular pressures on the basis of alterations in left ventricular compliance most frequently caused by myocardial ischemia. In fact, up to $50 \%$ of patients with heart failure have left-ventricular diastolic dysfunction (2). Diuretics are presently the cornerstone of therapy for patients with pulmonary edema from heart failure $(3,4)$. In the injured lung, because of increased permeability of the alveolar-capillary membrane, pulmonary edema occurs even at relatively low microvascular hydrostatic pressure. When ventricular pre-load is reduced in canine models of acute lung injury, alveolar edema formation is decreased (5). In humans with the acute respiratory distress syndrome (ARDS), weight gain and positive fluid balance are associated with poor outcome, and it has been proposed that a cause and effect relationship exists between survival and negative fluid balance (6-9).

The outcome of patients with acute hypoxemic respiratory failure improves when lung epithelial function is restored and pulmonary edema resolves $(10,11)$. Pulmonary edema is cleared out of the alveoli by active $\mathrm{Na}^{+}$transport $(12-14)$. $\mathrm{Na}^{+}$is transported across the alveolar epithelium predominantly by apical amiloride-sensitive sodium channels and $\mathrm{Na}^{+}, \mathrm{K}^{+}$-ATPase, and water follows isosmotically via aquaporins $(12,13,15,16)$. There is experimental evidence from alveolar epithelial cell monolayers and animal models that increasing alveolar epithelial $\mathrm{Na}^{+}$channels and $\mathrm{Na}^{+}, \mathrm{K}^{+}$-ATPase increases active $\mathrm{Na}^{+}$transport across the alveolar surface and thus the ability of the lungs to clear edema $(13,16-18)$. For example, recent studies have shown that dopamine and $\beta$-adrenergic agonists isoproterenol increase lung edema clearance by stimulating apical $\mathrm{Na}^{+}$channels and $\mathrm{Na}^{+}, \mathrm{K}^{+}$-ATPase activity in the alveolar epithelium of rats (18-20).

The kidneys maintain sodium and water homeostasis and thus play a critical role in the regulation of extracellular fluid composition and volume. Sodium reabsorption across the renal 

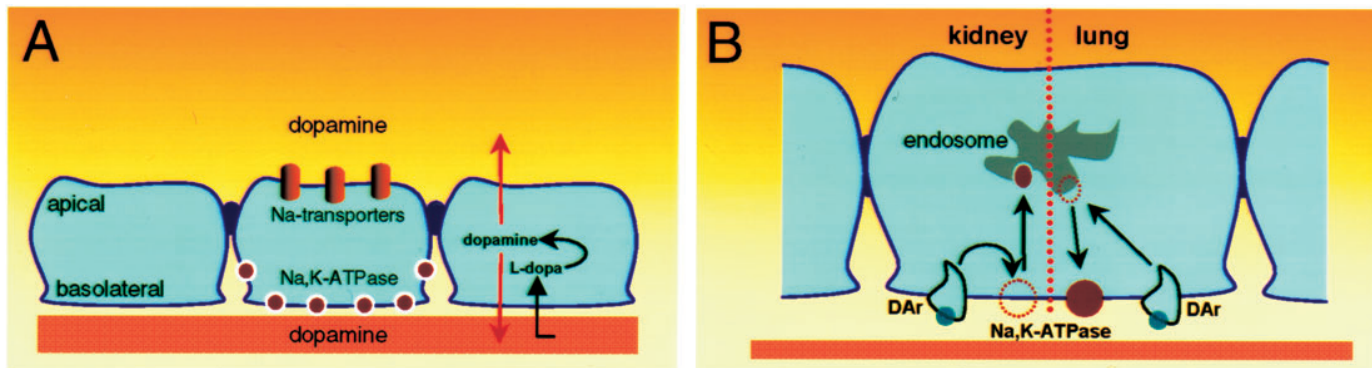

Figure 1. Dopamine effects on alveolar epithelial cells and renal PCT cells. $(A)$ Once dopamine is produced from its precursor L-dopa, it leaves to the luminal membrane (where it affects the sodium-dependent entry mechanisms located at the apical domain of the cells) and to the interstitium (where it regulates active sodium trans-

port at the basolateral domain the cells). (B) Dopamine has two distinct effects: in the renal epithelium it inhibits $\mathrm{Na}^{+}, \mathrm{K}^{+}$-ATPase activity, whereas in the lung alveolar epithelium it stimulates its activity. Inhibition is brought about by a reduction in the amount of active units present at the plasma membrane, whereas stimulation is accomplished by recruiting new molecules to the plasma membrane from endosomal compartments.

tubules also represents a driving force for the transport of potassium, hydrogen ions, phosphate, and calcium, among many other solutes, by the polar cells lining the nephron. Mechanisms governing these transport processes are targeted, by numerous regulatory hormones, and impaired function of such mechanisms often results in disorders that are complex, difficult to manage, and can lead to severe morbidity. For example, the development of hypertension, regardless of its mechanism, is often the result of an altered renal set point for sodium. In this respect, mutations in sodium channels (21) and/or defective hormonal responses (22), as well as abnormal function and regulation of $\mathrm{Na}^{+}, \mathrm{K}^{+}$ATPase by dopamine, have been described $(23,24)$.

\section{ORGAN-SPECIFIC PRODUCTION AND EFFECTS OF DOPAMINE OUTSIDE THE CENTRAL NERVOUS SYSTEM}

Since the 1970s attention has been growing on the peripheral actions of dopamine, not only for its ability to interact with its own receptor, but also focused on the complex responses elicited by its interaction with other catecholamine receptors. Because dopamine can also be produced outside the central nervous system, it raised the possibility of physiologic functions in other target organs.

Lung alveolar epithelial cells and cells from kidney proximal convoluted tubules represent an important source of extraneuronal dopamine, which has a significant role in local organ physiology. Circulating L-dopa (the dopamine precursor) enters the epithelial cell primarily through a sodium-independent, $\mathrm{pH}$-sensitive transporter recently identified in the kidney as type 2 L-amino acid transporter (25) and to a smaller extent (25\%) via a sodium-dependent transporter, and is converted into dopamine by L-amino acid dopa decarboxylase (26) (Figure 1A). It is believed that the uptake of L-dopa rather than the converting enzyme is the rate-limiting step in the production of dopamine. Despite the heterogeneity of the kidney nephron segments, dopamine produced within the proximal tubule cell can be secreted into the lumen (using the same transporter) and act as a paracrine agent along the nephron segments (27). At present it is not known whether in alveolar cells the locally formed dopamine follows the same route to the alveolar space or is secreted into the interstitium. However, both perfusion through the pulmonary circulation and instillation of dopamine into the alveolar space significantly increase alveolar fluid absorption, suggesting similar physiologic distribution (20).

During development, when the renal function has not yet matured, renal dopamine production and its physiologic actions are absent. Instead, dopamine is produced within the small intestine where it exerts its role as an important modulator of sodium and water homeostasis (28-30). This scavenger function of intes- tinal dopamine for the control of sodium and water balance is apparently limited to the immediate postnatal period.

In the mature organs, production of dopamine by renal proximal tubule cells could be triggered by a high salt intake (31), a phenomenon critical for maintaining sodium homeostasis by modulating urinary sodium excretion. Likewise, it was recently demonstrated that alveolar epithelial cells produce dopamine in vitro. Moreover, when rats were given a tyrosine-rich diet, there was an increase in dopamine production as well as an increase in alveolar fluid reabsorption (32). These observations suggest that dopamine may affect sodium and water transport across the alveolar cells and thereby constitute a first-level barrier that maintains the alveolar space free of edema fluid. These data complement previous reports showing that exogenous dopamine (given via the pulmonary circulation or in the airspace instillate) increases alveolar fluid reabsorption by more than $50 \%$ in normal lungs (17). In addition, dopamine increased alveolar fluid reabsorption to a similar degree in several models of lung injury, including acute hyperoxia and ventilation-induced lung injury, and in a model of acute congestive heart failure $(19,20,33,34)$.

\section{DOPAMINE-NA ${ }^{+}, \mathrm{K}^{+}$-ATPASE AXIS IN RENAL AND ALVEOLAR LUNG EPITHELIA: DISTINCT CELLULAR NETWORKS}

Dopamine produced in the kidney (which does not affect renal blood flow or glomerular filtration rate), as well as exogenously administrated dopamine (in so called "renal doses"), increases urinary sodium excretion by reducing tubular sodium reabsorption due to the inhibition of $\mathrm{Na}^{+}, \mathrm{K}^{+}$-ATPase activity $(35,36)$ and $\mathrm{Na}^{+} / \mathrm{H}^{+}$-exchanger activity (37). Dopamine, also at relatively low doses, increases active $\mathrm{Na}^{+}$transport and thus alveolar fluid reabsorption (20).

A distinct intracellular signaling network is assembled at the cell basolateral membrane interface, by which dopamine specifically regulates the $\mathrm{Na}^{+}, \mathrm{K}^{+}$-ATPase. There are significant and almost opposite effects of dopamine on the renal and alveolar epithelium (Figure 1B). In kidney cells initiation of the response to dopamine is confined to the plasma membrane, whereas in the lung alveolar epithelium it is initiated at the endosomal compartments. The primary effect in renal cells is to remove active $\mathrm{Na}^{+}, \mathrm{K}^{+}$-ATPase units from the plasma membrane (38) thereby reducing the capacity of these cells to promote vectorial sodium transport. In the lung, by contrast, dopamine increases $\mathrm{Na}^{+}, \mathrm{K}^{+}$-ATPase activity by increasing the cell surface expression of active pumps that are recruited from intracellular compartments (39), thereby increasing sodium and water (that follows isosmotically) transport out of the alveolar spaces. 

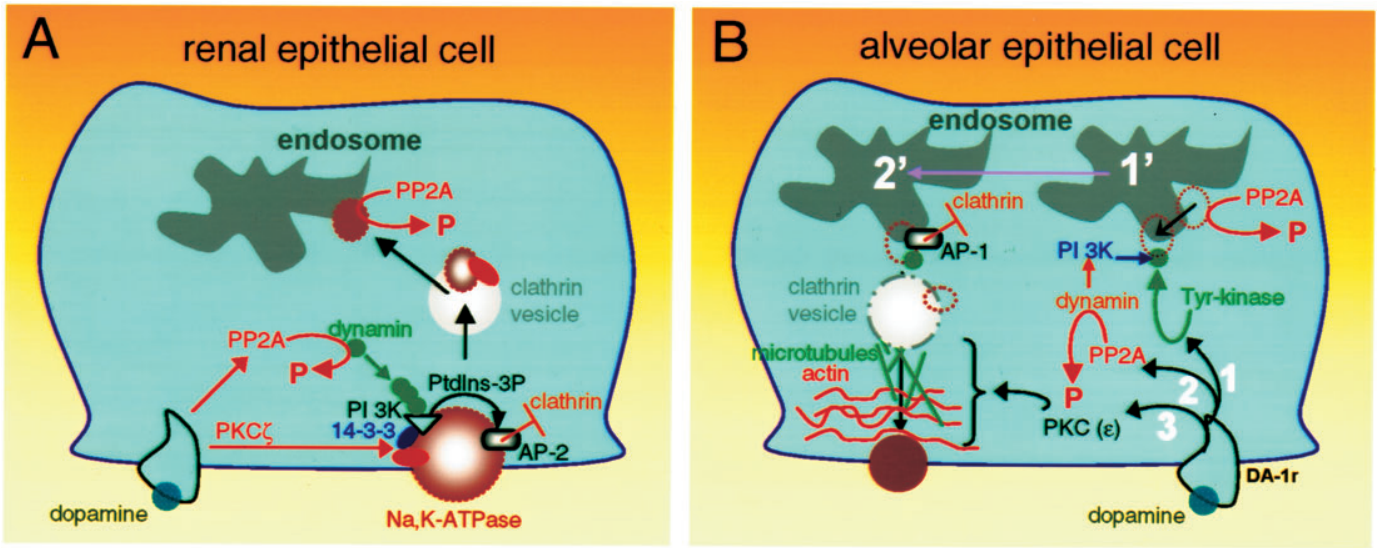

Figure 2. Signaling networks operating in the renal $(A)$ and lung alveolar epithelia $(B)$ responsible for the dopamine effects on $\mathrm{Na}^{+}, \mathrm{K}^{+}$-ATPase activity. For a detailed explanation see description within the text.

\section{Dopamine-Mediated $\mathrm{Na}^{+}, \mathrm{K}^{+}$-ATPase Endocytosis in Renal Tubule Cells}

The signaling networks responsible for dopamine-mediated $\mathrm{Na}^{+}, \mathrm{K}^{+}$-ATPase endocytosis connect the mediator (DA receptor) and the effector $\left(\mathrm{Na}^{+}, \mathrm{K}^{+}\right.$-ATPase), which begins with phosphorylation of the $\mathrm{Na}^{+}, \mathrm{K}^{+}$-ATPase $\alpha$-subunit at the plasma membrane (Figure 2A). Activation of protein kinase $\mathrm{C}$ (PKC) in response to dopamine is limited to the $\mathrm{PKC}-\zeta$ isoform, which is activated by the arachidonic acid metabolite, 20-hydroxyeicosatetraenoic acid $(40,41)$. Phosphorylation of the Ser-18 residue constitutes the triggering mechanism leading to $\mathrm{Na}^{+}, \mathrm{K}^{+}$-ATPase endocytosis of both the $\alpha$ - and $\beta$-subunits $(42,43)$. Although Ser-18 is present only in the rodent $\mathrm{Na}^{+}, \mathrm{K}^{+}$-ATPase $\alpha$-isoform, the presence of a phosphorylated Ser-11 residue within the human $\alpha$-isoform is sufficient to cause its endocytosis. Critical to this process is the activation of a phosphatidylinositol 3-kinase (44), for which phosphorylation of the $\mathrm{Na}^{+}, \mathrm{K}^{+}$-ATPase N-terminus is essential (45). The mechanism of activation does not follow a conventional pathway for this type of kinases. Instead, the PI 3-kinase type $\mathrm{A}$ that is activated by dopamine binds to a prolinerich domain within the $\mathrm{Na}^{+}, \mathrm{K}^{+}$-ATPase $\mathrm{N}$-terminus that is adjacent to the plasma membrane, and this interaction requires an $\mathrm{SH} 3$ domain present in the kinase $\mathrm{p} 85 \alpha$ regulatory subunit. It was originally thought that phosphorylation was necessary for inducing a conformational change within the $\mathrm{N}$-terminus structure that will make the proline-rich domain available for binding of the PI 3-kinase p85 $\alpha$ subunit. However, after structural comparisons to the SERCA it became apparent that the proline residues are not particularly hidden, but are rather exposed for potential protein-protein interactions. How is phosphorylation at the $\mathrm{N}$-terminus serine residue translated into binding and activation of PI 3-kinase? The answer to this puzzle lies with the 14-3-3 proteins, whose functions as scaffolding proteins are mediated by their binding to phosphorylated Ser/Thr residues. In this case, the 14-3-3€ isoform binds, in response to dopamine, simultaneously to the phosphorylated Ser-18 residue within the $\mathrm{Na}^{+}, \mathrm{K}^{+}$-ATPase $\alpha$-subunit (46) and to the PI 3-kinase p85 $\alpha$ subunit, thereby serving as an anchor between the phosphorylation site (Ser-18) and the proline-rich domain where the PI 3-kinase has its binding.

The location, assembly, and activation of the above-mentioned signaling molecules constitute the endocytic pathways network that precedes the formation and exit from the plasma membrane of clathrin-coated vesicles containing $\mathrm{Na}^{+}, \mathrm{K}^{+}$-ATPase molecules. The association of clathrin with the $\mathrm{Na}^{+}, \mathrm{K}^{+}$ ATPase $\alpha$-subunit indicates its position at the right site where endocytosis occurs, whereas the presence of PI 3-kinase near the plasma membrane facilitates the generation of catalytic products (e.g., phosphatidyl inositol 3-phosphate) required for the binding of adaptor protein-2 (AP-2) to the tyrosine-537 located in the main cytoplasmic loop of the $\mathrm{Na}^{+}, \mathrm{K}^{+}$-ATPase $\alpha$-subunit $(47,48)$. Binding of AP-2 not only selects the cargo to be internalized, but also recruits clathrin to the plasma membrane and initiates its polymerization and the formation of the clathrin-coated pit.

The central role of the PI 3-kinase appears not only to be limited to the hydrolysis of plasma membrane inositols, which facilitates AP-2 binding, but also for recruiting dynamin to the coated pit (47). The precise molecular nature of such interaction it is not known, nor is it clear whether it requires the intervention of a linking protein, such as syndapin-2 (which appears to be a likely candidate). Simultaneously to activation of PKC- $\zeta$, dopamine also triggers the activation of protein phosphatase $2 \mathrm{~A}$ isoform, leading to dephosphorylation of dynamin (49). Cycling between the phosphorylated-dephosphorylated states of dynamin is a prerequisite for its self-assembly at the neck of the clathrin-coated pit, where it is critical for fission of the vesicle.

\section{Dopamine Increases Plasma Membrane Expression of $\mathrm{Na}, \mathrm{K}$-ATPase in Alveolar Epithelial Cells}

In lung epithelia, dopamine-dependent increases in $\mathrm{Na}^{+}, \mathrm{K}^{+}$ATPase activity involves two mechanisms. The first is that in which activation of $D_{1}$ receptor subtype results in rapid recruitment of $\mathrm{Na}^{+}, \mathrm{K}^{+}$-ATPase molecules from intracellular compartments to the plasma membrane (39); the second is by increasing transcription (via activation of $\mathrm{D}_{2}$ receptor subtype) of the $\mathrm{Na}^{+}, \mathrm{K}^{+}$-ATPase $\beta_{1}$ isoform that results in increased $\mathrm{Na}^{+}, \mathrm{K}^{+}$ATPase activity in cells that have been exposed to dopamine for $24 \mathrm{~h}$. (50).

Contrary to the manner in which this process occurs in the kidney, the short-term signals generated by dopamine at the plasma membrane are transduced in a selective manner to the endosomal compartments from where the $\mathrm{Na}^{+}, \mathrm{K}^{+}$-ATPase molecules are recruited and transported to the plasma membrane (Figure 2B). The initial event that triggers the recruitment process appears to be the phosphorylation of a Tyr-5 residue within the $\alpha_{1}$-subunit (Figure 2B, 1) (M. L. Butti, L. Dada, Z. Chen, K. Ridge, J. I. Sznajder, and A. M. Bertorello, unpublished observation). This event promotes the binding and activation of PI 3-kinase (Type 1A). The increased production of phosphatidylinositol 3-P that follows the activation of PI3-kinase is necessary for facilitating the binding of AP1 to the $\alpha_{1}$-subunit, which precedes clathrin recruitment. The anchor of PI 3-kinase to the $\mathrm{Na}^{+}, \mathrm{K}^{+}$-ATPase $\alpha_{1}$-subunit (Tyr-5 residue) will additionally bind to dynamin and guide this molecule to the site of clathrin-coated pit formation 
(containing $\mathrm{Na}^{+}, \mathrm{K}^{+}$-ATPase molecules) to promote its fission and formation of the clathrin vesicle.

It appears that activation of PKCs also represents a critical signal-not, however, at the initial stage, but presumably later during vesicle motion (39). Dopamine activates $\mathrm{PKC}-\delta$ and PKC- $\epsilon$ in alveolar epithelial cells, and both isoforms are necessary for increasing $\mathrm{Na}^{+}, \mathrm{K}^{+}$-ATPase activity and its cell surface insertion. The fact that the activation of PKC- $\delta$ occurs before that of PKC- $\epsilon$ indicates a compartmentalized process and therefore the possibility of distinct cellular targets. Because PKC- $\delta$ is activated within $30 \mathrm{~s}$ of incubation with dopamine, it is speculated that it may act in the process associated with clathrin vesicle formation (adaptor protein phosphorylation, etc.). Activation of PKC- $\epsilon$ occurs after $2.5 \mathrm{~min}$, suggesting a mechanisms of action involving the mechanical forces (such as actin dynamics) involved in propelling $\mathrm{Na}^{+}, \mathrm{K}^{+}$-ATPase-containing vesicles to the plasma membrane (Figure $2 \mathrm{~B}, 3$ ). The later is supported by the observations that filamentous actin recognizes and bind directly to a hexapeptide motif that is unique to the regulatory $\mathrm{C} 1$ domain of PKC- $\epsilon(51,52)$. The $\mathrm{Na}^{+}, \mathrm{K}^{+}$-ATPase-containing vesicles located in the cell cytoplasm display a "random walk" type of motion (53). Upon incubation of cells with dopamine, a proportion of these vesicles display unidirectional motion that requires an intact microtubule system as well as a dynamic actin cytoskeleton. Thus, it is likely that a signaling mechanism involving PKC- $\epsilon$ might be responsible for the changes in the cytoskeletal network that facilitates the motion of the $\mathrm{Na}^{+}, \mathrm{K}^{+}$-ATPase molecules to the plasma membrane.

Similarly to renal epithelia, activation of dopamine receptors in alveolar epithelial cells is also associated with activation of protein phosphatases, specifically the PP2A isoform (54). This could be important at two different levels: (1) During endocytosis the $\mathrm{Na}^{+}, \mathrm{K}^{+}$-ATPase becomes dephosphorylated in the endosomes; thus, by increasing PP2A activity, dopamine could also accelerate the dephosphorylation of the $\mathrm{Na}^{+}, \mathrm{K}^{+}$-ATPase $\alpha$-subunits present in such endosomes so that in this "dephosphorylated" status they could leave the endosomal compartment. (2) It could be responsible for dephosphorylation of dynamin and promote its self-assembly at the neck of the coated pit (similarly to plasma membrane endocytosis) and release of the vesicles from the endosomes (Figure 2B, 2).

Interestingly, the long-term $(>24 \mathrm{~h})$ effect of dopamine (via $\mathrm{D}_{2}$ receptors) that results in higher $\mathrm{Na}^{+}, \mathrm{K}^{+}$-ATPase activity is mediated by activation of the classical MAPK pathway, via RAS, RAF-1 (but not Grb2-SOS), resulting in Erk1/2 transcriptional activation of the $\mathrm{Na}^{+}, \mathrm{K}^{+}$-ATPase $\beta_{1}$ isoform. This sequence of events leads to the increase in $\mathrm{Na}^{+}, \mathrm{K}^{+}$-ATPase units at the plasma membrane and increased $\mathrm{Na}^{+}, \mathrm{K}^{+}$-ATPase activity. Similarly to the short-term effect of dopamine, PKC- $\epsilon$ also mediates the $\mathrm{D}_{2}$-dependent activation of the MAPK pathway by regulating transcriptional events (55) through mechanisms that have not yet been elucidated.

\section{MEDIATOR VERSUS EFFECTOR: WHERE LIES THE SPECIFICITY?}

The specificity within the signaling network controlling whether the $\mathrm{Na}^{+}, \mathrm{K}^{+}$-ATPase undergoes endocytosis or translocation to the plasma membrane, apparently resides in the effector (target) and not in the mediator (specific receptors). Similarities between the kidney cells and lung alveolar epithelial cells regulating $\mathrm{Na}^{+}, \mathrm{K}^{+}$-ATPase endocytosis could be found and support this hypothesis. For example, during hypoxia alveolar fluid clearance is impaired which is due, in part, to decreased $\mathrm{Na}^{+}, \mathrm{K}^{+}$-ATPase activity due to a reduction in the number of active molecules at the alveolar epithelial cell plasma membrane (56). The responses generated by the hypoxic condition are mediated by the production of mitochondrial reactive oxygen species that leads to activation of a PKC- $\zeta$ isoform and phosphorylation of the $\mathrm{Na}^{+}, \mathrm{K}^{+}$ATPase $\alpha$-subunit within its Ser-18 residue in alveolar epithelial cells, triggering the endocytic removal of active $\mathrm{Na}^{+}, \mathrm{K}^{+}$-ATPase molecules (56).

Importantly, the dual and opposite physiologic and pharmacologic effects of dopamine on kidney and lung epithelia might be useful in the treatment of patients with fluid overload and edema. In the kidney, dopamine inhibits the $\mathrm{Na}^{+}, \mathrm{K}^{+}$-ATPase by inducing PKC-mediated phosphorylation and endocytosis of $\mathrm{Na}^{+}, \mathrm{K}^{+}$-ATPase molecules from the plasma membrane into intracellular pools, which results in decreased activity and natriuresis, leading to a better control of extracellular volume while also preventing or mitigating the development of high blood pressure. Conversely, in the lungs dopamine via early activation of tyrosine kinase increases $\mathrm{Na}^{+}, \mathrm{K}^{+}$-ATPase activity by promoting its recruitment from endosomal compartments, and transport to the plasma membrane, thus resulting in increased alveolar fluid reabsorption, which is crucial to restore normal gas exchange across the lungs.

What determines the difference between the two target organs? Whereas we have discussed the mechanistic differences between the two systems, the reasons for the lungs and the kidneys choosing different directions (kidney $=$ plasma membrane $\rightarrow$ endosome, lungs $=$ endosome $\rightarrow$ plasma membrane) are as yet unknown. One can speculate that the latter is determined by the fact that body homeostasis requires increase sodium/fluid removal from the alveoli to facilitate gas exchange, whereas in the kidney it requires a reduction of sodium transport to prevent fluid/salt overload on a high sodium diet. Possibly, a cell-specific "sensing or scaffolding" (still to be identified) could be responsible for the difference in organ response. Finally, understanding the different regulatory mechanisms along the Dopamine-Na,KATPase axis that are organ specific and identifying the different signaling partners and their hierarchical organization during cellular responses to dopamine may be of benefit to develop strategies aimed at resolving pulmonary edema, fluid overload, or saltsensitive hypertension.

Acknowledgments: The authors are especially thankful to Professor Adrian I. Katz for critical reading of this article and constructive criticisms. The authors acknowledge the superb scientific contributions from members of our laboratories.

\section{References}

1. Yeaman C, Grindstaff KK, Nelson WJ. New perspectives on mechanisms involved in generating epithelial cell polarity. Physiol Rev 1999;79: 73-98

2. Cleland JGF. Heart failure: a medical hydra. Lancet 1998;352:si1-si2.

3. Gammage M. Treatment of acute pulmonary edema: diuresis or vasodilatation? Lancet 1998;351:382-383.

4. Prewitt RM, McCarthy J, Wood LDH. Treatment of acute low pressure pulmonary edema in dogs: relative effects of hydrostatic and oncotic pressure, nitroprusside and PEEP. J Clin Invest 1981;67:409-419.

5. Sznajder JI, Zucker A, Wood LDH, Long GR. The effects of plasmapheresis and hemofiltration on canine acid aspiration pulmonary edema. Am Rev Respir Dis 1986;34:222-228.

6. Simmons RS, Berdine GG, Seidenfeld JJ, Prihoda TJ, Harris GD, Smith JD, Gilbert TJ, Mota E, Johanson WG Jr. Fluid balance and the adult respiratory distress syndrome. Am Rev Respir Dis 1987;135:924-929.

7. Eisenberg PR, Hansbrough JR, Anderson D, Schuster DP. A prospective study of lung water measurements during patient management in an intensive care unit. Am Rev Respir Dis 1987;136:662-668.

8. Humphrey H, Hall J, Sznajder I, Silverstein M, Wood L. Improved survival in ARDS patients associated with a reduction in pulmonary capillary wedge pressure. Chest 1990;97:1176-1180.

9. Schuller D, Mitchell JP, Calandrino FS, Schuster DP. Fluid balance during pulmonary edema: is fluid gain a marker of a cause of poor outcome? Chest 1991;100:1068-1075. 
10. Ware LB, Matthay MA. Alveolar fluid clearance is impaired in the majority of patients with acute lung injury and the acute respiratory distress syndrome. Am J Respir Crit Care Med 2001;163:1376-1383.

11. Matthay MA, Wiener-Kronish JP. Intact epithelial barrier function is critical for resolution of alveolar edema. Am Rev Respir Dis 1990;142: $1250-1257$.

12. Matalon S, Lazrak A, Jain L, Eaton DC. Invited review: biophysical properties of sodium channels in lung alveolar epithelial cells. $J$ Appl Physiol 2002;93:1852-1859.

13. Sznajder JI, Rutschman DH, Ridge KM, Olivera W. Mechanisms of lung liquid clearance during subacute hyperoxia in isolated rat lungs. $\mathrm{Am}$ J Respir Crit Care Med 1995;151:1519-1525.

14. Olivera WG, Ridge KM, Sznajder JI. Lung liquid clearance and alveolar epithelial Na,K-ATPase during acute hyperoxia and recovery in rats. Am J Respir Crit Care Med 1995;152:1229-1234.

15. Matalon S, Bridges RJ, Benos DJ. Amiloride-inhibitable Na+ conductive pathways in alveolar type II pneumocytes. Am J Physiol 1991;260:L90L96.

16. Folkesson HG, Matthay MA, Hasegawa H, Kheradmand F, Verkman AS. Transcelluar water transport in lung alveolar epithelium through mercury-sensitive water channels. Proc Natl Acad Sci USA 1994;91: 4970-4974.

17. Barnard ML, Olivera WG, Rutschman DM, Bertorello AM, Katz AI, Sznajder JI. Dopamine stimulates sodium transport and liquid clearance in rat lung epithelium. Am J Respir Crit Care Med 1997;156:709714.

18. Saldias F, Friedman E, Ridge KM, Lecuona E, Barnard ML, Sznajder JI. Modulation of lung liquid clearance by Isoproterenol in rat lungs. Am J Physiol 1998;18:694-701.

19. Saldias F, Lecuona E, Comellas A, Ridge KM, Sznajder JI. Dopamine restores lung ability to clear edema in rats exposed to hyperoxia. $A m$ J Respir Crit Care Med 1999;159:626-633.

20. Barnard ML, Ridge KM, Saldias F, Friedman E, Gare M, Guerrero C, Leuona E, Bertorello AM, Katz AI, Sznajder JI. Stimulation of the dopamine 1 receptor increases lung edema clearance. Am J Respir Crit Care Med 1999;160:982-986.

21. Rossier BC, Pradervand S, Schild L, Hummler E. Epithelial sodium channel and the control of sodium balance: interaction between genetic and environmental factors. Annu Rev Physiol 2002;64:877-897.

22. Ferrari P. Genetics of the mineralocorticoid system in primary hypertension. Curr Hypertens Rep 2002;4:18-24.

23. Zeng C, Wang D, Asico LD, Welch WJ, Wilcox CS, Hopfer U, Eisner GM, Felder RA, Jose PA. Aberrant D1 and D3 dopamine receptor transregulation in hypertension. Hypertension 2004;43:654-660.

24. Efendiev R, Krmar RT, Ogimoto G, Zwiller J, Tripodi G, Katz AI, Bianchi G, Pedemonte CH, Bertorello AM. Hypertension-linked mutation in the adducin $\alpha$-subunit leads to higher AP2- $\mu 2$ phosphorylation and impaired $\mathrm{Na}^{+}, \mathrm{K}^{+}$-ATPase trafficking in response to GPCR signals and intracellular sodium. Circ Res 2004;95:1100-1108.

25. Soares-Da-Silva P, Serrao MP, Pinho MJ, Bonifacio MJ. Cloning and gene silencing of LAT2, the L-3,4-dihydroxyphenylalanine (L-DOPA) transporter, in pig renal LLC-PK1 epithelial cells. FASEB J 2004;18: 1489-1498.

26. Soares-da-Silva P, Serrao MP. Outward transfer of dopamine precursor L-3,4-dihydroxyphenylalanine (L-dopa) by native and human P-glycoprotein in LLC-PK(1) and LLC-GA5 col300 renal cells. J Pharmacol Exp Ther 2000;293:697-704.

27. Carey RM. Renal dopamine system: paracrine regulator of sodium homeostasis and blood pressure. Hypertension 2001;38:297-302.

28. Lucas-Teixeira V, Vieira-Coelho A, Soares-da-Silva P. Food intake abolishes the response of rat jejunal $\mathrm{Na}(+), \mathrm{K}(+)$-ATPase to dopamine. $J$ Nutr 2000;130:877-881.

29. Finkel Y, Eklöf AC, Granquist L, Soares-da-Silva P, Bertorello AM. Endogenous dopamine modulates jejunal sodium transport during high salt diet in young but not in adult rats. Gastroenterology 1994;107: 675-679.

30. Vieira-Coelho MA, Teixeira VL, Finkel Y, Soares-da-Silva P, Bertorello AM. Dopamine inhibits jejunal $\mathrm{Na}^{+}, \mathrm{K}^{+}$-ATPase activity during high salt diet in young but not in adult rats. Am J Physiol 1998;275:G1317G1323.

31. Soares-da-Silva P, Pestana M, Fernandes MH. Involvement of tubular sodium in the formation of dopamine in the human renal cortex. $J$ Am Soc Nephrol 1993;9:1591-1599.
32. Adir Y, Azzam Z, Leal S, Pesce L, Lecuona E, Dumasius V, Factor P, Bertorello A, Young J, Ridge KM, et al. Augmentation of endogenous dopamine increases lung liquid clearance. Am J Respir Crit Care Med 2004:169:757-763.

33. Azzam ZS, Saldias F, Comellas A, Ridge KM, Rutschman DH, Sznajder JI. Cathecolamines increases lung ability to clear edema in rats with high hydrostatic pulmonary circulation pressures. J Appl Physiol 2001; 90:1088-1094.

34. Saldias F, Comellas A, Pesce L, Lecuona E, Sznajder JI. Dopamine increases lung liquid clearance during mechanical ventilation. $A m J$ Physiol 2002;83:L136-L143.

35. Bertorello AM, Aperia A. Proximal tubule $\mathrm{Na}+-\mathrm{K}+$-ATPase activity is inhibited during high-salt diet: evidence for DA-mediated effect. $\mathrm{Am}$ J Physiol 1988;254:F795-F801.

36. Satoh T, Cohen HT, Katz AI. Different mechanisms of renal Na$\mathrm{K}$-ATPase regulation by protein kinases in proximal and distal nephron. Am J Physiol 1993;265:F399-F405.

37. Felder CC, Campbell T, Albrecht F, Jose PA. Dopamine inhibits $\mathrm{Na}(+)-\mathrm{H}+$ exchanger activity in renal BBMV by stimulation of adenylate cyclase. Am J Physiol 1990;259:F297-F303.

38. Chibalin AV, Katz AI, Berggren PO, Bertorello AM. Receptor -mediated inhibition of epithelial $\mathrm{Na}^{+}, \mathrm{K}^{+}$-ATPase is associated with endocytosis of its $\alpha$ - and $\beta$-subunits. Am J Physiol 1997;273:C1458-C1465.

39. Ridge KM, Dada L, Lecuona E, Bertorello AM, Katz AI, Mochly-Rosen D, Sznajder JI. Dopamine-induced exocytosis of Na,K-ATPase is dependent on the activation of protein kinase $\mathrm{C}$ epsilon and delta. $\mathrm{Mol}$ Biol Cell 2002;13:1381-1389.

40. Efendiev R, Bertorello AM, Pedemonte CH. PKC- $\beta$ and PKC- $\zeta$ mediate opposing effects on epithelial $\mathrm{Na}^{+}, \mathrm{K}^{+}$-ATPase activity. FEBS Lett 1999;456:45-48.

41. Nowicki S, Chen SL, Aizman O, Cheng XJ, Li D, Nowicki C, Nairn A, Greengard P, Aperia A. 20-Hydroxyeicosa-tetraenoic acid (20 HETE) activates protein kinase $\mathrm{C}$ : role in regulation of rat renal $\mathrm{Na}+, \mathrm{K}+-$ ATPase. J Clin Invest 1997:99:1224-1230.

42. Chibalin AV, Pedemonte CH, Katz AI, Feraille E, Berggren PO, Bertorello AM. Phosphorylation of the catalytic $\alpha$ subunit constitutes a triggering signal for $\mathrm{Na}^{+}, \mathrm{K}^{+}$-ATPase endocytosis. J Biol Chem 1998;273: 8814-8819.

43. Chibalin AV, Ogimoto G, Pedemonte CH, Pressley TA, Katz AI, Féraille E, Berggren PO, Bertorello AM. Dopamine-induced endocytosis of $\mathrm{Na}^{+}, \mathrm{K}^{+}$-ATPase is initiated by phosphorylation of Ser18 in the rat $\alpha$-subunit and is responsible for the decreased activity in epithelial cells. J Biol Chem 1999;274:1920-1927.

44. Chibalin AV, Zierath JR, Katz AI, Berggren PO, Bertorello AM. Phosphatidylinositol 3-kinase-mediated endocytosis of renal $\mathrm{Na}^{+}, \mathrm{K}^{+}$-ATPase a subunit in response to dopamine. Mol Biol Cell 1998;9:1209-1220.

45. Yudowski GA, Efendiev R, Pedemonte CH, Katz AI, Berggren PO, Bertorello AM. Phosphoinositide-3 kinase binds to a proline-rich motif in the $\mathrm{Na}^{+}, \mathrm{K}^{+}$-ATPase $\alpha$-subunit and regulates its trafficking. Proc Natl Acad Sci USA 2000;97:6556-6561.

46. Efendiev R, Chen Z, Krmar RT, Uhles S, Katz AI, Pedemonte CH, Bertorello AM. The 14-3-3 protein translates the $\mathrm{Na}^{+}, \mathrm{K}^{+}$-ATPase $\alpha_{1}$-subunit phosphorylation signal into binding and activation of phosphoinositide 3-kinase during endocytosis. J Biol Chem 2005;280:1627216277.

47. Ogimoto G, Yudowski GA, Barker CJ, Köhler M, Katz AI, Féraille E, Pedemonte CH, Berggren PO, Bertorello AM. G protein-coupled receptors regulate $\mathrm{Na}^{+}, \mathrm{K}^{+}$-ATPase activity and endocytosis by modulating the recruitment of AP-2 and clathrin. Proc Natl Acad Sci USA 2000;97:3242-3247.

48. Cotta Doné S, Leibiger IB, Efendiev R, Katz AI, Leibiger B, Berggren PO, Pedemonte $\mathrm{CH}$, Bertorello AM. Tyrosine-537 within the $\mathrm{Na}^{+}, \mathrm{K}^{+}-$ ATPase $\alpha$-subunit is essential for AP-2 binding and clathrin-dependent endocytosis. J Biol Chem 2002;277:17108-17111.

49. Efendiev R, Yudowski GA, Zwiller J, Leibiger IB, Katz AI, Berggren $\mathrm{PO}$, Pedemonte $\mathrm{CH}$, Bertorello AM. Relevance of dopamine signals anchoring dynamin-2 to the plasma membrane during $\mathrm{Na}^{+}, \mathrm{K}^{+}$. ATPase endocytosis. J Biol Chem 2002;277:44108-44114.

50. Guerrero C, Pesce L, Lecuona E, Ridge K, Sznajder JI. Dopamine regulates $\mathrm{Na}, \mathrm{K}$-ATPase in alveolar epithelial cells via MAPK activation. Am J Physiol 2001;281:L79-L85.

51. Prekeris R, Mayhew MW, Cooper JB, Terrian DM. Identification and localization of an actin-binding motif that is unique to the epsilon isoform of protein kinase $\mathrm{C}$ and participates in the regulation of synaptic function. J Cell Biol 1996;132:77-90. 
52. Prekeris R, Hernandez EM, Mayhew MW, White MK, Terrian DM. Molecular analysis of the interactions between protein kinase C-epsilon and filamentous actin. J Biol Chem 1998;273:26790-26798.

53. Bertorello AM, Komarova Y, Smith K, Leibiger IB, Efendiev R, Pedemonte $\mathrm{CH}$, Borisy G, Sznajder JI. Analysis of $\mathrm{Na}^{+}, \mathrm{K}^{+}$-ATPase motion and incorporation into the plasma membrane in response to $\mathrm{G}$ proteincoupled receptor signals in living cells. Mol Biol Cell 2003;14:11491157.

54. Lecuona E, Garcia A, Sznajder JI. A novel role for protein phosphatase
$2 \mathrm{~A}$ in the dopaminergic regulation of $\mathrm{Na}, \mathrm{K}$-ATPase. FEBS Lett 2000;481:217-220.

55. Guerrero C, Pesce L, Lecuona E, Ridge KM, Sznajder JI. Dopamine activates ERK's in alveolar epithelial cells via RAS-PKC dependent and GRB2/SOS independent mechanisms. Am J Physiol 2002;282: L1099-L1107.

56. Dada LA, Chandel NS, Ridge KM, Pedemonte CH, Bertorello AM, Sznajder JI. Hypoxia-induced endocytosis of Na,K-ATPase in alveolar epithelial cells is mediated by mitochondrial reactive oxygen species and PKC-ל. J Clin Invest 2003;111:1057-1064. 